An oil suspension of potassium hydride, transferred to a flask, was allowed to settle and most of the oil decanted with a double-ended needle. Then the potassium hydride was washed with pentane $(3 \times 100 \mathrm{~mL})$. To this oil-free potassium hydride $(12 \mathrm{~g}, 300 \mathrm{mmol})$ suspended in THF $(150 \mathrm{~mL})$ was added a THF solution $(250 \mathrm{~mL})$ of $3(76 \mathrm{~g}$, $200 \mathrm{mmol}$ ) slowly via a double-ended needle with vigorous stirring. The reaction became slightly exothermic after a 10-30-min induction period. The reaction was monitored both by hydrolysis of centrifuged aliquots and by ${ }^{11} \mathrm{~B}$ NMR. It was complete within $2 \mathrm{~h}$, producing the addition compound, K 9-O-DIPGF-9-BBNH, $4(0.48 \mathrm{M}, 96 \%$ yield): ${ }^{11} \mathrm{~B}$ NMR $\delta 1.33(\mathrm{br}, \mathrm{s})$ : IR $\nu 2038 \mathrm{~cm}^{-1}(\mathrm{~s})$. Hydride and potassium were determined as $\mathrm{H}_{2}$ and $\mathrm{KOH}$ following hydrolysis; boron was estimated as 1,5-cycloctanediol following oxidation by alkaline hydrogen peroxide: [H] $=0.48 \mathrm{M} ;[\mathrm{K}]=0.48 \mathrm{M} ;[\mathrm{B}]=0.50 \mathrm{M}$. Therefore, a stoichiometry of $\mathrm{K}: \mathrm{B}: \mathrm{H}$ of $1: 1: 1$ was established.

The following procedure for the reduction of pivalophenone to $(R)-(+)-2,2$-dimethyl-1-phenylpropanol is representative of the asymmetric reductions. The THF solution $(1.0 \mathrm{M}, 10 \mathrm{~mL})$ of pivalophenone $(10 \mathrm{mmol})$, precooled to $-78^{\circ} \mathrm{C}$, was added to the solution $(0.48 \mathrm{M}$, $23 \mathrm{~mL})$ of the reagent $4(11 \mathrm{mmol})$ at $-78^{\circ} \mathrm{C}$ via a double-ended needle. After $40 \mathrm{~h}$, unreacted hydride was quenched by injecting anhydrous $\mathrm{HCl}$ in ee precooled to $-78^{\circ} \mathrm{C}$. Then the mixture was raised to $25^{\circ} \mathrm{C}$, and the reduction product was extracted with pentane after hydrolysis by dilute $\mathrm{HCl}$ followed by conversion of the borinic acid moiety into the "ate" complex ${ }^{4 a}$ using aqueous $\mathrm{NaOH}$. The pentane layer was washed with brine, dried $\left(\mathrm{MgSO}_{4}\right)$, and filtered, and the solvent was evaporated. Iistillation of the residue provided $1.42 \mathrm{~g}$ of $(R)-(+)-2,2$-dimethyl-1phenylpropanol $\left(92 \%\right.$ yield, bp $114-118^{\circ} \mathrm{C} / 16$ torr, [lit ${ }^{5}$ bp $130-140^{\circ} \mathrm{C} / 20$ torr] containing a small amount of starting ketone). The alcohol product was further purified by preparative GLC $(20 \%$ Carbowax $20 \mathrm{M}, 6 \mathrm{ft} \times 1 / 2$ in. column, $\left.150^{\circ} \mathrm{C}\right)$, and the rotation was measured: $[\alpha]^{22} \mathrm{D}$ $+25.96^{\circ}$ ( $c 2.2$, benzene), $100 \%$ ee based on the maximum reported rotation $[\alpha]_{\mathrm{D} \text {,max }}+25.9^{\circ}$ (c 2.2, benzene).$^{7} \mathrm{Ca}$ pillary GLC analysis (Supelcowax, $15 \mathrm{~m}$ ) of MTPA esters ${ }^{9}$ of the product alcohol revealed a composition of $98.4 \% R$ $+1.6 \% \mathrm{~S}$ (i.e, $96.8 \%$ ee), in close agreement with optical rotation measurement.

In conclusion, the present study provides a convenient and simple synthesis of an effective chiral borohydride reagent containing a single hydride per molecule and consisting of a single characterized reducing species. The new reagent reduces prochiral alkyl phenyl ketones and relatively hindered aliphatic ketones, effectively providing high optical yields of the corresponding alcohols consistently enriched in their $R$ enantiomers. This study can be extended to the synthesis of a variety of simple, stable, and characterized chiral borohydride reagents incorporated with various chiral auxiliaries. Consequently, one should be able to design improved chiral borohydride reagents by systematic studies of the effect of the chiral moiety on the asymmetric induction. Such systematic studies are underway.

Acknowledgment. We are grateful to the United States Army Research Office for the financial assistance (ARO DAAG 29-85-K-0062) which made this investigation possible. B. T. Cho also thanks the Korean Science and

(7) MacLeod, R.; Welch, F. J.; Mosher, H. S. J. Am. Chem. Soc. 1960 82,876 .

(8) Nasipuri, D.; Sarker, G. J. Indian Chem. Soc, 1967, 44, 165

(9) Dale, J. A.: Mosher, H. S. J. Am. Chem. Sor. 1973, 95, 512.
Engineering Foundation for the postdoctorate fellowship which enabled him to perform this research.

\author{
Herbert C. Brown,* Won Suh Park, Byung Tae Cho \\ Richard B. Wetherill Laboratory \\ Purdue University \\ West Lafayette, Indiana 47907 \\ Received December 30, 1985
}

\section{An Asymmetric Synthesis of Chiral 4,4-Disubstituted Cyclohexenones in High Enantiomeric Purity}

Summary: An efficient approach to the title compounds in $>95 \%$ ee has been accomplished by metalation and alkylation of chiral bicyclic lactams derived from $\delta$-keto acids and (1S,2S)-2-amino-1-phenyl-1,3-propanediol.

Sir: Our recent successes in reaching chiral compounds containing a quaternary stereocenter ${ }^{1}$ has led to 3,3 -disubstituted cyclopentenones $3 .^{2}$ Thus, dialkylation of the readily available bicyclic lactam 1 by successive treatment with LDA and two different alkyl halides to 2 , followed by reduction and hydrolysis, gave 3 in $>99 \%$ ee. It was

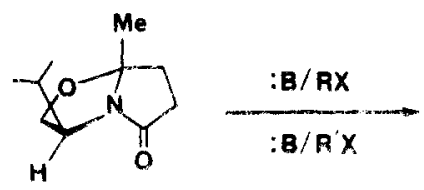

(s) -1

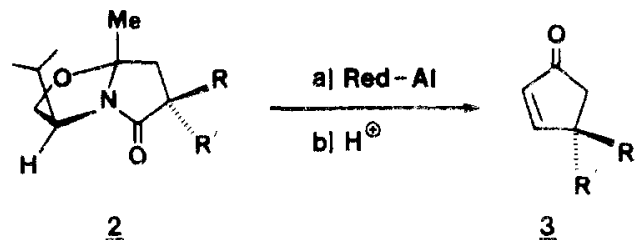

assumed that the homologated bicyclic lactam 4, under similar conditions, would provide the chiral cyclohexenone, 5. However this was not to be the case since all attempts to reduce the lactam carbonyl to aldehyde gave unwanted side products, the major one being the piperidone 6 . The

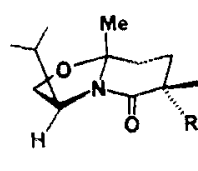

4

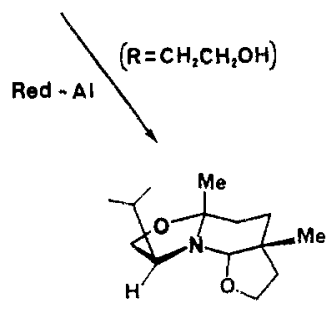

?

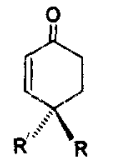

$\underline{5}$

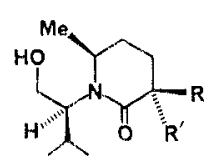

므. latter arises from reductive cleavage of the oxazolidine ring.

(1) Meyers, A. I.; Harre, M.; Garland, R. J. Am. Chem. Soc. 1984, 106, 1146

(2) Meyers, A. I.; Wanner, K. T. Tetrahedron Lett. 1985, 26, 2047. Meyers, A. I.; Lefker, B. A. J. Org. Chem, in press. 
Scheme I<smiles>[R]C1([R])CCC2(C)OCC(CO)N1C2=O</smiles>

A
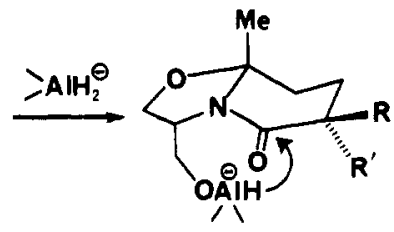

B<smiles>O=CO</smiles><smiles>[R]C1([R])CCC2(C)OCC(CO2)N1C</smiles>

c

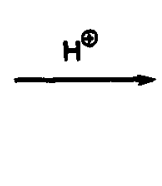<smiles>[R]C1([R])C=CC(=O)CC1</smiles>

$\underline{5}$<smiles>N[C@H]1[C@H](c2ccccc2)[C@@H](CO)[C@H](O)[C@H]1c1ccccc1</smiles>

Scheme II<smiles>CC12CCCC(=O)N1[C@@H](C(O)c1ccccc1)CO2</smiles><smiles></smiles>

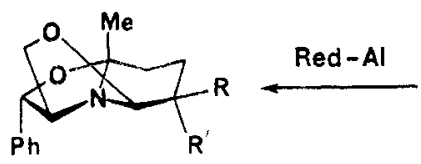

14

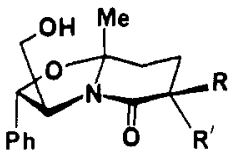

$\frac{\text { LDA-HMPA }}{R^{\prime} X}$

13a, $R=M e, R^{\prime}=P^{\prime} C_{2}$ 13b, $R=\mathrm{PhCH}_{2}, \mathrm{R}^{\prime}=\mathrm{Me}$ 13c, $R=\mathrm{PhCH}_{2}, \mathrm{R}^{\prime}=$ Allyl<smiles>[R]C([R])(O)C(C)CC(C)=O</smiles>

15

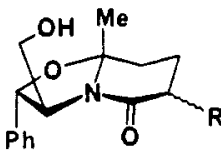

12, $\mathrm{R}=\mathrm{Me}, \mathrm{PhCH}_{2}$, Allyl<smiles>[R]C1([R])C=CC(=O)CC1</smiles>

$\underline{5 a}, R=M e, R^{\prime}=P_{h C H}$
$\underline{5 b}, R=P h C H_{-}, R^{\prime}=M e$
$\underline{5 c}, R \boxminus P h C H_{2}, R^{\prime}=A l l y \mid$
During the course of this work, it was observed that bicyclic lactams, containing a hydroxyethyl or aminoethyl substituent, $4\left(\mathrm{R}=\mathrm{CH}_{2} \mathrm{CH}_{2} \mathrm{OH}\right)$ were readily reduced to the keto aldehyde precursor 7 and hydrolyzed to the cyclohexenone 8 in $75 \%$ yield and in $>99 \%$ ee. ${ }^{3}$ This may be attributed to the intermediate aluminum salt acting as a "hinge" to rapidly deliver hydride in an intramolecular fashion. If this conclusion is accurate, then the asymmetric synthesis of chiral 4,4-disubstituted cyclohexenones is presently limited only to those cases where a hydroxyl or amino group is suitably placed in the molecule. On the other hand, if the chiral bicyclic lactams were to possess a hydroxyl group to allow carbonyl reduction to readily occur (A) then hydride deliver via the "hinge effect"4 (B) would furnish the keto aldehyde precursor (C) and ultimately lead after hydrolysis to the cyclohexenones 5 (Scheme I). Using the process in Scheme I as a working model, it was decided to evaluate the commercially available amino diol $9^{5}$ as the chiral auxiliary. Treatment of the latter with 1.0 equiv of 4 -acetylbutanoic acid ${ }^{5}$ (benzene, reflux, $16 \mathrm{~h}$ ) gave the bicyclic lactams 10 and 11 in a $14: 84$ ratio with approximately $2 \%$ of another lactam

(3) Meyers, A. I.; Hanreich, R.; Wanner, K. T. J. Am. Chem. Soc. 1985, 107,7776 .

(4) For an excellent example of the hinge effect on stereo- and regioselective reductions with aluminum hydrides-alkoxy ate complexes, see: Thompson, H. W.; McPherson, E. J. Org. Chem. 1977, 42, 3350.

(5) Aldrich Chemical Co., Milwaukee, WI. isomer of 11 (Scheme II). Recrystallization (EtOAc-Hex) gave pure $11\left(\mathrm{mp} 98-99{ }^{\circ} \mathrm{C}\right.$ ) in $60-65 \%$ yield. It was believed that 11 would provide the crucial test outlined in Scheme I, and to this end, metalation (2.5 equiv of LDA, $\mathrm{THF},-78^{\circ} \mathrm{C}$ ) of 11 followed by alkyl halides (3.0 equiv, $-78^{\circ} \mathrm{C}$ ) gave 12 in $70-80 \%$ yields as a mixture of endo-exo isomers. The latter mixture is of no consequence since repeating the metalation (2.5 equiv of LDA, $20 \%$ HMPA-THF, $-78^{\circ} \mathrm{C}$, followed by 2.0 equiv of $\mathrm{RX}$ ) gave $13 \mathbf{a}(97: 3), 13 \mathbf{b}(75: 25)$, and $13 \mathbf{c}(82: 18)$ with the diastereomer from endo entry predominating. Thus, as noted earlier, ${ }^{1-3}$ alkylation of the lactam enolate proceeds mainly from the bottom face. Chromatography (silica gel, 1:1 EtOAc-hexane) gave pure 13 in $50-80 \%$ yields. ${ }^{6,7}$ To confirm the stereochemistry, an X-ray structure was performed on 13a and showed the stereochemistry of the bicyclic lactam and the two alkyl substituents are correct as shown.

When the dialkylated bicyclic lactams were subjected to reductions with Red-Al (1.2 equiv, toluene, -60 to 25 ${ }^{\circ} \mathrm{C}, 24 \mathrm{~h}$ ) the tricyclic aminals 14 were obtained and treated, in their crude form, with an aqueous $1 \mathrm{M}$ solution of tetrabutylammonium dihydrogen phosphate in ethanol $\left(1: 1,2 \mathrm{~h}\right.$ at $25^{\circ} \mathrm{C}, 16 \mathrm{~h}$ at reflux). The intermediate keto

(6) Alkylations were carried out with methyl iodide, benzyl bromide, or allyl bromide. The highest diastereoselectivity was noted when the larger electrophile was added in the second alkylation step. 
aldehyde 15 was bypassed during the hydrolysis, giving only the 4,4-dialkylcyclohexenones 5a-c. Both enantiomers were thus formed $\left([\alpha]_{D}\right.$ for $\mathbf{5 a},-65.58^{\circ} ;[\alpha]_{D}$ for $\mathbf{5 b}$, $\left.+64.83^{\circ}\right)$ along with $5 \mathrm{c}\left([\alpha]_{\mathrm{D}}+48.98^{\circ}\right) .^{7}$ Presumably, the acid-catalyzed hydrolysis of 14 also provided the proper conditions for the aldol cyclizations.

As an extension of this methodology, we prepared the bicyclic lactam 16 from 9 and 5-oxoheptanoic acid (toluene, reflux $12 \mathrm{~h}$ ). The lactam 16 was isolated pure, after recrystallization, in $68 \%$ yield $\left(\mathrm{mp} 83-85^{\circ} \mathrm{C}\right)$. Double al-

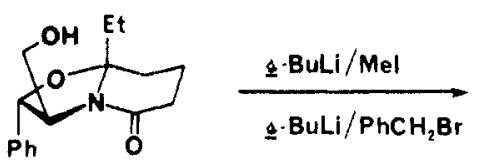

16

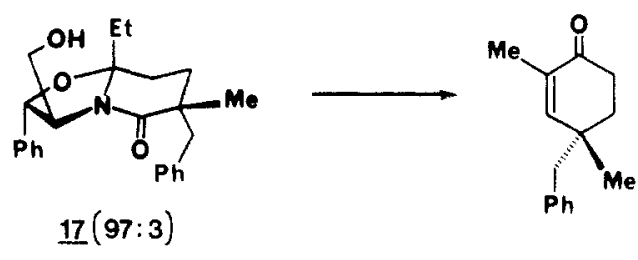

18

kylation (2.5 equiv of sec-BuLi, THF, $-78^{\circ} \mathrm{C}, 3.0$ equiv of MeI; 2.5 equiv of sec-BuLi, 4:1 THF-HMPA, 4.0 equiv of benzyl bromide) gave 17 as a $97: 3$ mixture of endo-exo

(7) Physical data. 13a: yield, 67\%; IR $\left(\mathrm{CCl}_{4}\right) 3350 \mathrm{br}, 2950,1620$, $1460,1425 \mathrm{~cm}^{-1} ;{ }^{1} \mathrm{H}$ NMR $\left(\mathrm{CDCl}_{3}\right) \delta 7.10-7.50(\mathrm{~m}, 10 \mathrm{H}), 4.68(\mathrm{~d}, J=8.4$ $\mathrm{Hz}, 1 \mathrm{H}), 4.20(\mathrm{br} \mathrm{s}, 1 \mathrm{H}), 4.03(\mathrm{dt}, J=2.2,8.6 \mathrm{~Hz}, 1 \mathrm{H}), 3.88(\mathrm{dd}, J=$ $2.2,11.3 \mathrm{~Hz}, 1 \mathrm{H}), 3.77$ (dd, $J=8.8,11.3 \mathrm{~Hz}, 1 \mathrm{H}), 3.38(\mathrm{~d}, J=13.0 \mathrm{~Hz}$ $1 \mathrm{H}), 2.10(\mathrm{~m}, 1 \mathrm{H}), 1.75(\mathrm{~m}, 2 \mathrm{H}), 1.48(\mathrm{~s}, 3 \mathrm{H}), 1.36(\mathrm{~s}, 3 \mathrm{H}), 1.05(\mathrm{~m}, 1$ H). 13b: yield, $60 \%$; IR $\left(\mathrm{CCl}_{4}\right) 3400 \mathrm{br}, 2950,1620,1460,1420 \mathrm{~cm}^{-1} ;{ }^{1} \mathrm{H}$ NMR $\left(\mathrm{CDCl}_{3}\right) \delta 7.10-7.50(\mathrm{~m}, 10 \mathrm{H}), 4.81(\mathrm{dd}, J=2.4,7.9 \mathrm{~Hz}, 1 \mathrm{H}), 4.65$ $(\mathrm{d}, J=8.6 \mathrm{~Hz}, 1 \mathrm{H}), 4.05(\mathrm{dt}, J=2.0,8.1 \mathrm{~Hz}, 1 \mathrm{H}), 3.86$ (ddd, $J=2.0$, $7.9,10.1 \mathrm{~Hz}, 1 \mathrm{H}$ ), 3.61 (ddd, $J=2.4,10.1,8.1 \mathrm{~Hz}, 1 \mathrm{H}), 3.41$ (d, $J=13.0$ $\mathrm{Hz}, 1 \mathrm{H}), 2.48(\mathrm{~d}, J=13.0 \mathrm{~Hz}, 1 \mathrm{H}), 1.50-2.00(\mathrm{~m}, 4 \mathrm{H}), 1.41(\mathrm{~s}, 3 \mathrm{H}), 0.77$ $(\mathrm{s}, 3 \mathrm{H})$. 13c: yield, $72 \%$; IR (CCl) $3350 \mathrm{br}, 2910,1620,1440,1410 \mathrm{~cm}^{-1}$; ${ }^{1} \mathrm{H}$ NMR $\left(\mathrm{CDCl}_{3}\right) \delta 7.15-7.60(\mathrm{~m}, 10 \mathrm{H}), 6.90(\mathrm{~m}, 1 \mathrm{H}), 5.20(\mathrm{~m}, 2 \mathrm{H}), 4.89$ (dd, $J=2.4,7.9 \mathrm{~Hz}, 1 \mathrm{H}), 4.64(\mathrm{~d}, J=6.1 \mathrm{~Hz}, 1 \mathrm{H}), 4.05(\mathrm{dt}, J=1.9,8.2$ $\mathrm{Hz}, 1 \mathrm{H}$ ), 3.85 (ddd, $J=1.9,7.9,10.1 \mathrm{~Hz}, 1 \mathrm{H}$ ), 3.61 (ddd, $J=2.4,8.2$ $10.1 \mathrm{~Hz}, 1 \mathrm{H}), 3.35(\mathrm{~d}, J=12.9 \mathrm{~Hz}, 1 \mathrm{H}), 2.75(\mathrm{dd}, J=7.2,13.6 \mathrm{~Hz}, 1 \mathrm{H})$ 2.48 (d, $J=12.9 \mathrm{~Hz}, 1 \mathrm{H}), 2.38$ (dd, $J=8.1,12.9 \mathrm{~Hz}, 1 \mathrm{H}), 1.90(\mathrm{~m}, 4 \mathrm{H})$ $0.63(\mathrm{~s}, 3 \mathrm{H})$. 5a: yield, $53 \%$; $[\alpha]_{\mathrm{D}}-65.58^{\circ}(c 1.04, \mathrm{EtOH})$; IR (film) 3040 $2935,2885,1680,1605,1490,1450,1415 \mathrm{~cm}^{-1} ;{ }^{1} \mathrm{H}$ NMR $\left(\mathrm{CDCl}_{3}\right)$ $7.10-7.40(\mathrm{~m}, 5 \mathrm{H}), 6.69(\mathrm{~d}, J=10.2 \mathrm{~Hz}, 1 \mathrm{H}), 5.90(\mathrm{~d}, J=10.2 \mathrm{~Hz}, 1 \mathrm{H})$, $2.75(\mathrm{~s}, 2 \mathrm{H}), 2.44(\mathrm{t}, J=6.9 \mathrm{~Hz}, 2 \mathrm{H}), 1.96(\mathrm{~d}, J=6.7 \mathrm{~Hz}, 1 \mathrm{H}), 1.79(\mathrm{~m}$, $1 \mathrm{H}), 1.13(\mathrm{~s}, 3 \mathrm{H})$. Anal. Calcd for $\mathrm{C}_{14} \mathrm{H}_{16} \mathrm{O}: \mathrm{C}, 83.95 ; \mathrm{H}, 8.05$. Found C, $83.84 ; \mathrm{H}, 8.01$. 5b: yield, $68 \% ;[\alpha]_{D}+64.83^{\circ}(c 1.02, \mathrm{EtOH}) ;{ }^{1} \mathrm{H}$ NMR $\left(\mathrm{CDCl}_{3}\right) \delta$ [same as above]. Anal. Calcd for $\mathrm{C}_{14} \mathrm{H}_{16} \mathrm{O}: \mathrm{C}, 83.95 ; \mathrm{H}, 8.05$. Found: $\mathrm{C}, 83.84 ; \mathrm{H}, 8.20$. 5e: yield, $47 \% ;[\alpha]_{\mathrm{D}}+48.98^{\circ}(\mathrm{c} 1.03, \mathrm{EtOH})$; IR (film) $3080,3040,2940,2875,1690,1650,1610,1500,1460,1395 \mathrm{~cm}^{-1}$ ${ }^{1} \mathrm{H}$ NMR $\left(\mathrm{CDCl}_{3}\right) \delta 7.10-7.40(\mathrm{~m}, 5 \mathrm{H}), 6.68(\mathrm{~d}, J=10.2 \mathrm{~Hz}, 1 \mathrm{H}), 5.96$ $(\mathrm{d}, J=10.2 \mathrm{~Hz}, 1 \mathrm{H}), 5.80(\mathrm{~m}, 1 \mathrm{H}), 5.13(\mathrm{~m}, 2 \mathrm{H}), 2.80(\mathrm{AB} \mathrm{q}, J=13.4$ $\mathrm{Hz}, 2 \mathrm{H}), 2.40(\mathrm{~m}, 1 \mathrm{H}), 2.20(\mathrm{t}, J=6.6 \mathrm{~Hz}, 1 \mathrm{H}), 1.90(\mathrm{~m}, 2 \mathrm{H}) .16$ : vield, $71 \%$; mp 83-85 ${ }^{\circ} \mathrm{C}\left(1: 4\right.$ EtOAc-hexane); $[\alpha]_{\mathrm{D}}+12.61^{\circ}$ (c 2.1, EtOH); IR (film) $1625 \mathrm{~cm}^{-1} ;{ }^{1} \mathrm{H}$ NMR $\left(\mathrm{CDCl}_{3}\right) \delta 7.36(\mathrm{~m}, 5 \mathrm{H}), 5.18(\mathrm{br}, 1 \mathrm{H}$, exchangeable with $\left.\mathrm{D}_{2} \mathrm{O}\right), 4.64(\mathrm{~d}, J=8.6 \mathrm{~Hz}, 1 \mathrm{H}), 3.97-4.10(\mathrm{~m}, 1 \mathrm{H}), 3.8 .6$ (dd, $J=11.2,2.2 \mathrm{~Hz}, 1 \mathrm{H}$ ), 3.72 (dd, $J=11.2,8.7 \mathrm{~Hz}, 1 \mathrm{H}$ ), $2.30-2.63(\mathrm{~m}$, $2 \mathrm{H}), 1.50-2.05(\mathrm{~m}, 6 \mathrm{H}), 0.94(\mathrm{t}, J=7.4 \mathrm{~Hz}, 3 \mathrm{H})$. Anal. Calcd for $\mathrm{C}_{16} \mathrm{H}_{21} \mathrm{NO}_{3}: \mathrm{C}, 69.79 ; \mathrm{H}, 7.69 ; \mathrm{N}, 5.09$. Found: $\mathrm{C}, 69.82 ; \mathrm{H}, 7.62 ; \mathrm{N}, 5.37$. 17 (pure endo-benzyl): yield, 81.2\%; ${ }^{1} \mathrm{H}$ NMR ( $\left.\mathrm{CDCl}_{3}\right) \delta 7.0-7.45(\mathrm{~m}, 5$ $\mathrm{H}), 5.55$ (dd, $J=6.9,1.2 \mathrm{~Hz}, 1 \mathrm{H}$, exchangeable with $\mathrm{D}_{2} \mathrm{O}$ ), 4.56 (d, $J=$ $8.4 \mathrm{~Hz}, 1 \mathrm{H}), 3.93-4.05(\mathrm{~m}, 1 \mathrm{H}), 3.67-3.90(\mathrm{~m}, 2 \mathrm{H}), 3.41(\mathrm{~d}, J=13 \mathrm{~Hz}$ $1 \mathrm{H}), 2.53(\mathrm{~d}, J=13 \mathrm{~Hz}, 1 \mathrm{H}), 1.50-2.10(\mathrm{~m}, 6 \mathrm{H}), 1.35(\mathrm{~s}, 3 \mathrm{H}), 0.85(\mathrm{t}$, $J=7.4 \mathrm{~Hz}, 3 \mathrm{H}$ ). 18: yield, $66 \%$; $[\alpha]_{\mathrm{D}}-39.70^{\circ}(\mathrm{c} 0.99$, EtOH); IR (film) $1680,1635 \mathrm{~cm}^{-1} ;{ }^{1} \mathrm{H}$ NMR $\left(\mathrm{CDCl}_{3}\right) \delta 7.05-7.37(\mathrm{~m}, 5 \mathrm{H}), 6.45(\mathrm{br} \mathrm{d}, 1 \mathrm{H})$, $2.73(\mathrm{~s}, 2 \mathrm{H}), 2.45(\mathrm{t}, J=6.8 \mathrm{~Hz}, 2 \mathrm{H}), 1.85-2.00(\mathrm{~m}, 1 \mathrm{H}), 1.76(\mathrm{~d}, J=$ $1.4 \mathrm{~Hz}, 3 \mathrm{H}), 1.65-1.79(\mathrm{~m}, 1 \mathrm{H}), 1.10(\mathrm{~s}, 3 \mathrm{H})$. Anal. Calcd for $\mathrm{C}_{15} \mathrm{H}_{18} \mathrm{O}$ : $\mathrm{C}, 84.07 ; \mathrm{H}, 8.47$. Found: $\mathrm{C}, 84.19 ; \mathrm{H}, 8.43$. 21: yield, $47 \% ;[\alpha]^{20}{ }_{\mathrm{D}} 122.2^{\circ}$ (c 0.32, EtOH); IR (film) $1665 \mathrm{~cm}^{-1} ;{ }^{1} \mathrm{H}$ NMR ( $\left.\mathrm{CDCl}_{3}\right) \delta 7.25-7.45$ (m, 5 H), $6.94(\mathrm{~d}, J=10.2 \mathrm{~Hz}, 1 \mathrm{H}), 6.13(\mathrm{~d}, J=10.2 \mathrm{~Hz}, 1 \mathrm{H}), 2.10-2.50(\mathrm{~m}$ $4 \mathrm{H}), 1.57(\mathrm{~s}, 3 \mathrm{H})$. Anal. Calcd for $\mathrm{C}_{13} \mathrm{H}_{14} \mathrm{O}: \mathrm{C}, 83.83 ; \mathrm{H}, 7.58$. Found: $\mathrm{C}, 83.56 ; \mathrm{H}, 7.59$. diastereomers. Flash chromatography (silica gel, 1:1 EtOAc-hexane) provided pure 17 in $81 \%$ yield. Reduction and hydrolysis to the cyclohexenone 18 was accomplished, as above, furnishing the enantiomerically pure product in $65 \%$ yield $\left.[\alpha]_{D}-39.70^{\circ}\right) .^{7}$

We also examined the asymmetric route to $(R)-(+)-4-$ phenyl-4-methylcyclohexenone, prepared earlier by Yamada $^{8}$ in $40-50 \%$ ee via the proline-derived enamine addition to methyl vinyl ketone. Our sequence began by condensing 9 with racemic 2-phenyl-5-oxohexanoic acid $(19)^{9}$ (benzene, reflux, $\left.16 \mathrm{~h}\right)$, producing $20(80 \%)$ along with an isomer similar to $10(20 \%)$. Due to difficulty in separation, the mixture of lactams was metalated (2.5 equiv of LDA, THF, $-78^{\circ} \mathrm{C}$ ) and alkylated with methyl iodide (1.8 equiv) and chromatographed (silica gel $30 \%$, EtOAc-hexane) to remove the isomeric lactam. The desired lactam $\left(53 \%\right.$ yield, $\left.\mathrm{mp} 122-123{ }^{\circ} \mathrm{C}\right)$ was reduced with Red-Al and hydrolyzed with $\mathrm{Bu}_{4} \mathrm{NH}_{2} \mathrm{PO}_{4}$ to give the cy-

$(\mathbf{s}, \mathbf{s})-\underline{9}+$<smiles>CC(=O)CCC(C(=O)O)c1ccccc1</smiles>

$( \pm)-\underline{19}$

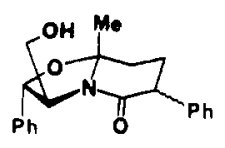

$\underline{20}$

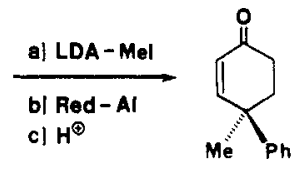

$\underline{21}$ clohexenone $(R)-(+)-21,[\alpha]^{20}{ }_{\mathrm{D}} 122.2^{\circ}\left(\right.$ lit. $\left.^{10}[\alpha]^{25}{ }_{\mathrm{D}} 122.5^{\circ}\right)$ in $99.8 \%$ ee.

In summary, we have described an efficient route to 4,4-disubstituted cyclohexenones in high enantiomeric excess using readily available materials, and work is in progress to extend this to more elaborate systems.

Acknowledgment. Financial support was provided by the National Institutes of Health, and K.T.W. acknowledges a postdoctoral Fellowship from the Deutsche Forschungsgemeinschaft. We also thank Professor O. P. Anderson and Joe Reibenspies for providing the X-ray structure of $13 \mathrm{a}$.

Supplementary Material Available: X-ray data for 13a $(9$ pages). Ordering information is given on any current masthead page.

(8) Yamada, S.; Otani, G. Tetrahedron Lett. 1969, 48, 4237. Soue, T. Hiroi, K.; Yamada, S. Chem. Pharm. Bull. 1973, 23, 2331. Schuster, D. I.; Brown, R. H.; Resnick, B. M. J. Am. Chem. Soc. 1978, 100, 4504.

(9) Prepared in a manner similar to that reported in ref 3 above. (10) The optical purity given in ref 8 was determined by conversion to 2-methyl-2-phenylglutaric anhydride and reported to be $130 \pm 2^{\circ}$. However, a recent report (Gilbert, J. C.; Giamalva, D. H.; Baze, M. E. J. Org. Chem. 1985, 50, 2557) has challenged the rotation by Yamada et al. as being too high and has revised the rotation, on the basis of enantiomeric purity determined by chiral shift reagents, to $122.2^{\circ}$. Our results, based on the lactam precursor to 21 (HPLC, $270-\mathrm{MHz},{ }^{1} \mathrm{H}$ NMR) showed that it was homogeneous with less than $0.3 \%$ of the other diastereomers.

A. I. Meyers,* Bruce A. Lefker Klaus Th. Wanner, R. Alan Aitken

Department of Chemistry Colorado State University

Fort Collins, Colorado 80523

Received February 3, 1986 